\title{
Kesadaran Beribadah Shalat Dzuhur Siswa Kelas X IPS dan Upaya Meningkatkannya di SMA Muhammadiyah 1 Palembang
}

\author{
Fadilatul Laily ${ }^{1}$, Aset Sugiana ${ }^{2}$ \\ 1UIN Raden Fatah Palembang, \\ ${ }^{2}$ UIN Sunan Kalijaga Yogyakarta
}

Kata Kunci:

Islamic Education Teachers, Religious Consciousness, Prayer Dhuhr.

*Correspondence Address: asetsugiana@gmail.com

\begin{abstract}
:
This research is intended to describe the religious consciousness of the praying dhuhr of students and the attempt to elevate it. This method of research involves qualitative work. Research data obtained from an Islamic religious teacher and student notebooks. The data analysis technique used that classifies, combines, interprets, and concludes. The study yielded the following conclusions: 1 . The religious consciousness of praying dhuhr of students X IPS class at Muhammadiyah school 1 of Palembang was divided into a) a student whose consciousness was very good/good, b) a student of sufficient self-awareness and c) students who had poor spiritual awareness and still needed much improvement. The factors of student awareness in worship are due to a) Internal factor that is the factor comes from within the student; b). external factors such as family, school factors, and community factors. 2. Teacher PAI's role in raising awareness of worship the dhuhr student prayer, which is: a) acts as a teacher; b). acts as a tutor; c) acts as a leader; d) played the scientist; e) acts as a link; f) acting as a renewal. The role is performed by teachers supported by way: a) breeding; b. motivation; c. example; d. awareness; and e. surveillance.
\end{abstract}

\section{PENDAHULUAN}

Pendidikan merupakan suatu proses dalam rangka mempengaruhi siswa agar dapat menyesuaikan diri sebaik mungkin terhadap lingkungannya dan dengan demikian akan menimbulkan perubahan dalam dirinya yang memungkinnya untuk berfungsi dalam kehidupan masyarakat. ${ }^{1}$ Salah satu alat untuk membimbing sesorang menjadi orang yang baik terutama pendidikan agama. Bimbingan adalah proses pemberian bantuan kepada individu dapat

1 Oemar Hamalik, Proses Belajar Mengajar, (Jakarta: PT Bumi Aksara, 2001), 79

2 Ermis Suryana, Bimbingan Konseling di Sekolah dan Madrasah, (Palembang: Noer Fikri, 2012), 2 memamahi dirinya sehingga sanggup mengarahkan diri dan dapat bertindak wajar sesuai dengan tuntutan dan keadaan keluarga dan masyarakat. ${ }^{2}$

Pelaksanaan pendidikan yang diberikan bukan hanya pada pengetahuan terhadap (Islam), tetapi juga terutama pada pelaksanaan dan pengamalan agama peserta didik dalam seluruh kehidupannya agar siswa dalam aktivitas kehidupannya tidak lepas dari pengalaman agama, berakhlak mulia, dan berkepribadian utama, berwatak sesuai dengan ajaran agama Islam. ${ }^{3}$

3 Abrul Rachman Shaleh, Pendidikan Agama dan Pembangunan Watak Bangsa, (Jakarta: PT Raja Grafindo Persada, 2005), 7-8 
Pendidikan Islam adalah salah satu upaya untuk menciptakan manusia cerdas yang memiliki keahlian dan keterampilan sehingga pada gilirannya dapat memainkan perannya, mengatasi persoalan ketenagakerjaan, dan pengangguran yang merupakan bagian penting persoalan sosial ekonomi masyarakat. ${ }^{4}$ Pendidikan dan pengajaran bukanlah memenuhi otak anak didik tetapi maksudnya menghasilkan peserta didik yang berkualitas, baik secara akademis, skil (keahlian) kematangan emosional, dan moral serta spritual dengan demikian, akan dihasilkan generasi masa depan yang siap hidup dengan tantangan zamannya. $^{5}$

Tujuan pendidikan nasional adalah tujuan umum dari sistem pendidikan nasional, tujuan ini merupakan tujuan jangka panjang dan sangat luas menjadi pedoman dari semua kegiatan atau usaha pendidikan di negara kita. ${ }^{6}$ Pada akhirnya tujuan pendidikan Islam itu tidak lepas dari tujuan nasional yang menciptakan manusia Indonesia seutuhnya, seimbang kehidupan duniawi dan ukhrawi. Dalam Al-Qur'an sudah jelas dikatakan bahwa manusia itu diciptakan untuk mengabdi kepada Allah SWT. Hal ini terdapat dalam AlQuran surat Adz-Zariyat ayat 56:

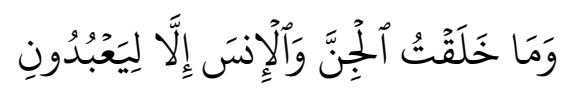

\section{Artinya: "Dan aku tidak menciptakan jin dan manusia melainkan}

4 Ta'dib, Jurnal Pendidikan Islam, (Vol. Xiv.No.01.Edisi Juni 2009), 141-142

5 Kunandar, Guru Profesioal, (Jakarta: Raja Wali Press, 2009), 40

6 Oemar Hamalik, Proses Belajar Mengajar, (Jakarta: PT Bumi Aksara, 2001), 81-82

${ }^{7}$ Al-Quran Dan Terjemah, (Bandung: Departemen Agama RI, 2013), 523 supaya mereka mengabdi kepada-Ku". (QS. Adz-Zariyat: $56)^{7}$

Pendidikan memiliki tanggung jawab dalam meningkatkan minat siswa, memperluas dan mengembangkan keilmuan mereka dan membantu mereka agar mampu menjawab tantangan dan gagasan baru dimasa mendatang. Pendidikan Islam adalah proses pembentukan kepribadian individu sesuai dengan nilai-nilai ilahiyah, sehingga individu yang bersangkutan dapat mencerminkan kepribadian muslim yang berakhlak Al karima. ${ }^{8}$

Peran guru sebagai pendidik profesional sesungguhnya sangat kompleks, tidak terbatas pada saat berlangsungnya interaksi edukatif di dalam kelas. Menurut James B. Borrow berpendapat peran guru itu menguasai dan mengembangkan materi pelajaran, merencanakan, mempersiapkan pelajaran sehari-hari mengontrol dan mengevaluasi kegiatan siswa. ${ }^{9}$

Dalam pendidikan guru merupakan contoh teladan bagi siswa disekolah. Dalam undang-undang yang dimaksud guru adalah pendidik profesional dan tugas utama mendidik, mengajar, membimbing, mengarahkan, melatih, menilai, dan mengevaluasi peserta didik pada pendidikan anak usia dini, jalur pendidikan formal, pendidikan dasar, dan pendidikan menengah. ${ }^{10}$

8 Rusmaini, Ilmu Pendidikan, (Depok: Pustaka Felicha, 2013), 9

${ }^{9}$ Akmal Hawi, Kompetensi Guru Pendidikan Agama Islam, (Jakarta: PT Raja Grafindo Persada, 2013), 15

10Undang-Undang Guru Dan Dosen, (Jakarta: Sinar Grafika, 2008), 3 
Guru merupakan salah satu di antara berbagai sumber dan media belajar. Maka dengan demikian peran guru dalam belajar ini menjadi luas dan lebih mengarah kepada peningkatan motivasi belajar siswa-siswa. Hal ini berarti bahwa guru hendaknya dapat mengembangkan cara dan kebiasaan belajar yang sebaik-baiknya. ${ }^{11}$ Guru merupakan komponen yang paling berpengaruh terhadap terciptanya proses dan hasil pendidikan yang

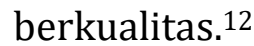

Berdasarkan observasi yang dilakukan peneliti pada tanggal 04 Agustus sampai dengan 17 September 2016 di SMA Muhammadiyah 1 Palembang. Diketahui bahwa sebagian siswa melakukan shalat dengan baik, namun hanya beberapa siswa yang rajin melaksanakan salat ada juga yang bermalas-malasan, bahkan harus ada guru menegur atau menyuruh salat baru siswa tersebut melaksanakan shalat. Terkadang siswa harus dibimbing dari kelas sampai ke mushalla barulah siswa tersebut melaksanakan shalat dengan baik.

Berdasarkan uraian latar belakang di atas peneliti tertarik untuk melakukan penelitian "Peran Guru PAI dalam Meningkatkan Kesadaran Beribadah Shalat Dzuhur Siswa Kelas X IPS di SMA Muhammadiyah 1 Palembang".

\section{METODE PENELITIAN}

Sesuai fokus penelitian yang mencoba mengukur kualitas dari kesadaran siswa, maka penelitian ini menggunakan jenis penelitian kualitatif deskriptif dengan teknik analisis

11 Slameto, Beelajar Dan Faktor-Faktor Yang Memprngaruhi, (Jakarta: Rineka Cipta, 2015), 98 sebagaimana dijabarkan oleh Miles and Huberman.

Pengumpulan data dilaksanakan menggunakan wawancara, observasi dan dokumentasi dengan didukung oleh Teknik pengabsahan data menggunakan triangulasi, baik data, sumber data maupun metode yang digunakan.

\section{HASIL PENELITIAN DAN PEMBAHASAN}

1. Kesadaran Beribadah Shalat Dzuhur Siswa Kelas X IPS 1 di SMA Muhammadiyah 1 Palembang Untuk mengetahui kesadaran beribadah shalat dzuhur. Peneliti melakukan wawancara dan observasi yang didapatkan secara langsung ketika di lapangan. Selain pemahaman bahwa kesadaran beribadah termasuk shalat dzuhur banyak sekali faktor yang mempengaruhinya yaitu ada faktor intern dan faktor ekstern dan pemahaman seorang siswa terhadap ajaran agama Islam juga sangat mempengaruhi. Dari hasil penelitian penulis yang dilakukan, kesadaran beribadah shalat dzuhur siswa kelas X IPS1 di SMA Muhammadiyah 1 Palembang terdapat berbagai tipe-tipe, yaitu: ${ }^{13}$

a. Para siswa yang kesadarannya sangat bagus/baik dengan ciriciri mereka yang penuh kesadarannya tanpa paksaan, tanpa dorongan, dan tanpa teguran dari seorang guru walaupun guru pembimbing di sana ada di dalam kelas, mereka dengan sigap setalah istirahat

12 Quantum, Jurnal Madrasah dan Pendidikan Agama Islam, (Vol.3 No.1 JanuariApril 2008), 68

${ }^{13}$ Hasil Observasi Siswa Kelas X IPS 1 pada hari Rabu Tanggal 19 Juli 2017 
dan mendengarkan azan mereka langsung menuju ke mushalla atau tetap di dalam kelas dan langsung mengambil wudhu untuk melaksanakan shalat dzuhur. Di sinilah para siswa yang penuh kesadarannya dan memang dari dalam diri mereka itu selalu melaksanakan shalat dzuhur baik wajib maupun shalat sunah,

b. Para siswa yang kesadarannya masuk dalam kategori cukup dengan indikator mereka shalat belum termotivasi dari dalam dirinya sendiri. Dalam arti mereka melaksanakan shalat karena ajakan teman, dan melakukan shalat takut dimarah oleh guru yang mengontrol atau guru yang ada di dalam kelas $\mathrm{X}$ IPS1. Shalat mereka belum tekun dan kontinu masih banyak yang bolong-bolong kadang hari ini shalat kadang besok tidak melakukan shalat, 3 . Para siswa yang kesadaran beribadahnya kurang dan masih perlu banyak di tingkatkan lagi, siswa tersebut melaksanakan ibadah shalat dikarenakan adanya paksaan dari guru yang mengontrol di setiap kelas atau guru yang memang terjadwal mengajar di dalam kelas X IPS1 di SMA Muhammadiyah 1 Palembang.

Dari uraian di atas, jelas terlihat bahwa kesadaran beribadah mereka sangat di pengaruhi dari dua faktor, hal ini di pengaruhi terhadap kesadaran beribadah siswa, di mana terdapat kebanyakan siswa yang rajin dan bagus melaksanakan ibadah shalat, namun ada sebagian siswa termasuk kategori

14 Hasil Wawancara dengan Pak Bustomi (Guru PAI Kelas X) pada Tanggal 24 Juli 2017 cukup terhadap kesadaran beribadah shalatnya, dan ada juga yang kurang giat dalam melakukan shalat dzuhur.

Faktor-faktor kesadaran siswa dalam beribadah:

a. Faktor Intern. Faktor intern ialah faktor yang berasal dari dalam diri siswa yang mencakup biologis siswa. Faktor biologis seperti kesehatan jasmani dan rohani sangat besar pengaruhnya terhadap beribadah shalat dzuhur, bila seseorang kesehatannya terganggu dapat mengakibatkan cepat lelah, tidak bergairah, dan tidak bisa melakukan shalat. Demikian halnya jika kesehatan rohani (jiwa) seseorang kurang baik, misalnya mengalami perasaan kecewa, ini bisa menggangu atau mengurangi semangat dalam melakukan shalat. Oleh karena itu, pemeliharaan kesehatan sangat penting bagi setiap orang, baik fisik maupun mental, agar badan tetap kuat, pikiran selalu segar dan bersemangat dalam melaksanakan kegiatan yang ada di sekolah dan melakukan shalat dzuhur. ${ }^{14}$

b. Faktor ektern adalah faktor dari luar diri seseorang yang memungkinkan untuk dapat mengembangkan fitrah beragama dengan sebaik-baiknya. Faktor eksternal ini berupa pendidikan yang diterima baik dilingkungan keluarga, sekolah dan masyarakat.15 1) faktor keluarga. Keluarga merupakan lingkungan pertama dan utama bagi anak oleh karena itu kedudukan keluarga dalam pengembangan kepribadian anak sangatlah dominan, dalam hal ini orang tua mempunyai peran yang sangat penting dalam upaya

15 Zuhdiyah, Psikologi Agama, (Palembang: Pustaka Felicha, 2012), 105 
peningkatan kesadaran beribadah shalat dzuhur bagi anak-anak mereka, seperti cara orangtua mendidik. Cara orang tua mendidik anaknya sangat besar pengaruhnya terhadap beribadah shalat anak. Mendidik anak tidak baik jika terlalu memanjakan dan tidak jaga terlalu keras. Dengan cara orang tua mendidik dan mencontohkan dengan baik, anak akan semakin mematuhi orang tua. 2) faktor sekolah. Dalam kaitannya dengan peran meningkatkan kesadaran beribadah para siswa, maka sekolah terutama dalam hal ini guru PAI mempunyai peran yang sangat penting dalam mengembangkan wawasan pemahaman, pembiasaan, mengamalkan ibadah atau akhlak yang mulia terhadap ajaran agama, terutama pelaksanaan ibadah shalat dzuhur. Dalam hal ini guru sangat sering memberikan motivasi dengan cara menceritakan amalanamalan apa saja yang didapatkan ketika mengerjakan shalat dzuhur, dari sinilah siswa di sini alhamdulillah tidak lagi meninggalkan shalat dzuhur. ${ }^{16}$ 3) faktor masyarakat. Masyarakat juga berpengaruhi terhadap beribadah shalat siswa, seperti kegiatan di luar sekolah seperti menari, olahraga, dan lainnya. Bila kegiatan tersebut dilakukan dengan berlebihan bisa mempengaruhi untuk tidak melaksanakan shalat. Teman bergaul juga bisa mempengaruhi jika teman bergaul yang tidak sesuai dengan nilai-nilai agama pasti mempengaruhi sifat yang jelek pada dirinya begitu pun sebaliknya.

Dari faktor tersebut, terkadang dari siswa itu sendiri terbawa dalam

16 Hasil wawancara (Siswa Kelas X IPS1) pada Tanggal 24 Juli 2017 masalah di rumahnya sehingga ketika melaksanakan shalat terkadang agak sedikit lesu tidak semangat. Karena faktor dari orang tua bahkan faktor dari sesama siswa, faktor dengan guru yang mempengaruhi siswa itu terkadang malas untuk beribadah khusus kelas $\mathrm{X}$ IPS1 di SMA Muhammadiyah 1 Palembang pada waktu shalat dzuhur. Guru PAI mengatakan bahwa harus memberikan pengetahuan kepada anak didik persoalan yang mudah, akan tetapi utnuk membentuk jiwa dan watak anak didik itulah perkara yang sulit bagi saya, sebab anak didik yang dihadapi adalah makhluk yang mempunyai otak dan potensi yang dipengaruhi oleh banyak hal, seperti tingkat keberagamaan masing-masing, teman pergaulannya, latar belakang keluarga dan masyarakat juga mempunyai pengaruh dalam kaitannya dengan kesadaran beribadah sholat dzuhur siswa. ${ }^{17}$

Adapun hasil wawancara peneliti mengenai bagaimana tingkat kebiasaan siswa terhadap kesadaran beribadah shalat dzuhur siswa, yaitu: a. Dimulai dari masuk sekolah sampai pulang sekolah melakukan kewajiban yang ada di sekolah termasuk shalat dzuhur, b. Waktu istrahat menjelang azan tetap di dalam kelas dan ada juga yang menuju ke musholah (jadwal shalat di mushola) dan bergegas mengambil wudhu dan bersiap-siap untuk melaksanakan shalat, c. Melakukan shalat dzuhurnya dengan sungguh-sungguh tanpa paksaan, d. Menyadari bahwa melakukan shalat dzuhur itu wajib dan harus dilakukan secara terus-menerus sebagaimana semestinya, e. Membawa mukena dari rumah untuk shalat dzuhur di sekolah, f. Melakukan shalat tidak hanya disekolah tetapi di rumah

17 Hasil Wawancara dengan Pak Bustomi (Guru PAI Kelas X) pada tanggal 24 Juli 2017 
juga karena kami mendapatkan buku shalat yang harus di tanda tangani oleh orang tu, g. Ada beberapa siswa melakukan shalatnya dengan mainmain atau tidak serius, h. Waktu shalat dzuhur ada beberapa siswi yang mengaku berhalangan untuk shalat padahal tidak. ${ }^{18}$

Dari observasi yang dilakukan peneliti bahwa tingkat kesadaran beribadah shalat dzuhur kelas X IPS1 di SMA Muhammadiyah 1 Palembang. Dapat di lihat dari beberapa siswa yang bersama-sama untuk mengambil wudhu setelah mendengar azan. Siswasiswa tersebut juga sudah membawa masing-masing mukena untuk mereka melakukan shalat walaupun ada beberapa siswa melakukan shalatnya dengan main-main. ${ }^{19}$

Berdasarkan hasil observasi dan wawancara di atas bahwa pembiasaan siswa berdampak pada kesadaran beribadah shalat dzuhur siswa kelas $\mathrm{X}$ IPS1 di SMA Muhammadiyah 1 Palembang, artinya para siswa sudah memiliki kesadaran yang baikdi dalam diri mereka untuk melaksanakan shalat. Mereka dari awal masuk sekolah sampai pulang sekolah tekun melakukan kewajiban yang ada, melakukan dengan sungguh-sungguh tanpa paksaan, melakukan terus-menerus, dan tidak lupa membawa mukena ke sekolah untuk melaksanakan shalat.Walaupun masih terdapat siswa yang tingkat kesadarannya kurang sehingga mereka tidak melaksanakan shalat dzuhur karena faktor kelelahan dari olahraga dan faktor malas.

Berdasarkan hasil dari wawancara dan observasi, di dapat kesadaran beribadah shalat dzuhur siswa kelas $\mathrm{X}$

18 Hasil wawancara (Siswa Kelas X IPS1), pada Tanggal 24 Juli 2017

19 Hasil Observasi Siswa Kelas X IPS1 pada hari Rabu 19 Juli dan Selasa 8 Agustus 2017
IPS1 di SMA Muhammadiyah 1 Palembang. Terkategori sangat baik dikarenakan banyak siswa yang melakukan shalat mencapai $90 \%$ tanpa paksaan, tanpa dorongan, karena memang dari diri sendiri mereka melakukan shalat dengan baik dan banyak juga yang melakukan shalat bukan hanya disekolah saja. tetapi juga shalat di rumah. Walaupun demikian terdapat siswa yang tingkat kesadaran mereka kurang sehingga tidak melakukan shalat dzuhur di SMA Muhammadiyah 1 Palembang.

2. Peran Guru PAI dalam Meningkatkan Kesadaran Beribadah Shalat Dzuhur Siswa Kelas X IPS 1 di SMA Muhammadiyah 1 Palembang Peneliti melakukan wawancara kepada guru PAI yaitu Bapak Muhammad Bustomi. Beliau juga merupakan lulusan sarjana pendidikan agama Islam, beliau mengajar mata pelajaran pendidikan agama Islam kelas $\mathrm{X}$ di SMA Muhammadiyah 1 Palembang. Dalam proses shalat, guru mempunyai tugas untuk mendorong, membimbing, dan memberi fasilitas shalat bagi siswa untuk mencapai tujuan serta guru mempunyai tanggung jawab untuk melihat segala sesuatu yang terjadi di dalam kelas. ${ }^{20}$

Hal ini senada dengan pendapat ibu Siti selaku guru PAI kelas X di SMA Muhammadiyah 1 Palembang. ${ }^{21}$ Beliau menjelaskan guru itu bukan hanya sekedar mengajar dan tetapi peran guru

${ }^{20}$ Hasil Wawancara dengan Pak Bustomi (Guru PAI Kelas X) Pada tanggal 24 Juli 2017

${ }^{21}$ Hasil Wawancara dengan Ibu Siti (Guru PAI Kelas X) Pada tanggal 24 Juli 2017 
lebih dari itu, selain mengajar juga mendidik serta menjadi contoh yang baik bagi siswanya. Peran guru PAI paling tidak yang harus dilakukan untuk meningkatkan kesadaran beribadah shalat dzuhur yaitu dengan membimbing siswa, dan mengajak siswa shalat tepat pada waktunya agar siswa tersebut terbiasa dengan kewajibannya.

Sedangkan menurut pak Bustomi guru PAI di kelas X IPS1, peran guru sangat banyak tidak hanyak mentransfer ilmu pengetahuan saja melainkan mendidik membimbing siswa. Berbagai faktor yang telah mempengaruhi siswa yaitu faktor kelelahan karena siswa banyak sekali kegiatan-kegiatan, faktor siswa mengganti pakaian baju olaraga untuk melaksanakan shalat. Kita sebagai guru PAI untuk bisa membiasakan kembali siswa untuk melaksanakan sholat dengan cara memotivasi siswa dengan cara melihat dan mengajak siswa untuk shalat. $^{22}$

Dari hasil observasi tidak jauh berbeda dengan yang dijelaskan oleh ibu Siti dan pak Bustomi, saat proses pembelajaran di mulai sebelum materi inti disampaikan guru terlebih dahulu memberikan motivasi kepada siswa, kemudian guru mengajar dengan baik, mengaitkan materi inti dengan materi lainnya, kemudian diakhiri proses pembelajaran dikelas guru memberikan tugas untuk bacaan shalat dan hafalan surat untuk shalat. $^{23}$

22 Hasil Wawancara dengan Pak Bustomi (Guru PAI Kelas X) Pada tanggal24 Juli 2017

${ }^{23}$ Hasil Observasi, Siswa Kelas X IPS1 pada hari Rabu 19 Juli 2017 dan Selasa 8 Agustus 2017
Dari keterangan di atas, dapat diketahui bahwa pada saat proses pembelajaran berlangsung, guru memberikan motivasi siswa agar lebih giat melakukan shalat, saat materi disampaikan guru memberikan penjelasan yang menghubungkan langsung dengan kehidupan sehari-hari sesuai dengan materi yang disampaikan. Hal ini membuat siswa mengerti dan paham materi yang disampaikan oleh guru.

Untuk mengetahui peran guru PAI dalam meningkatkan kesadaran beridabah shalat dzuhur siswa kelas X IPS1. Peneliti menggunakan konsep dari Adams dan Dickey bahwa peran guru sesungguhnya sangat luas, meliputi :

a. Guru Sebagai Pengajar,

b. Guru Sebagai Pembimbing,

c. Guru Sebagai Ilmuwan,

d. Guru Sebagai Pribadi,

e. Guru Sebagai Penghubung,

f. Guru Sebagai Pembaharu,

g. Guru Sebagai Pembangunan. ${ }^{24}$

Peneliti melakukan wawancara kepada bapak Bustomi dan ibu Siti selaku guru PAI yang secara langsung ketika di lapangan, adapun hasil wawancara peneliti mengenai peran guru PAI dalam meningkatkan kesadaran beribadah shalat dzuhur siswa, yaitu:

a. Guru Berperan sebagai Pengajar

Seorang guru yang baik selalu datang tepat waktu dikelas saat jam pelajaran dimulai, tanpa harus di beritahu terlebih dahulu oleh siswa. Hal tersebut dapat dijadikan contoh yang sangat baik untuk siswa agar 123-126 
tidak datang terlambat. Dari hasil wawancara dengan pak Bustomi, beliau selalu datang lebih awal dan langsung menuju ke kelas dikarenakan beliau mengajar di kelas X IPS1 pada hari Rabu jam 06.40-08.25. Sebelum mengajar beliau memberikan waktu 20 menit kepada siswa untuk sholat dhuha, tadarus dan berdoa. Sebelum ke pembelajaran inti.Beliau setiap pagi mengajarkan untuk bacaan ibadah bacaan shalat dan harus hafal. Jadi untuk ibadah mereka sendiri tidak terlalu repot karena mereka telah hafal semua dan telah tahu gerakangerakan menurut sunah yang di ajarkan kepada Rosulullah SAW. ${ }^{25}$

\section{b. Guru Berperan sebagai Pembimbing \\ Guru berkewajiban mem-} berikan bantuan kepada siswa agar mereka mampu menegenal diri sendiri. $^{26}$ Hal ini jika dikaitkan dengan data yang peneliti dapatkan dilapangan tentang peran guru dalam meningkatkan kesadaran beribdah shalat dzuhur siswa akan terlihat adanya suatu relevensi dimana guru PAI yang mengajar di SMA Muhammadiyah 1 Palembang berperan dalam meningkatkan kesadaran beribdah shalat dzuhur siswa yaitu : a. Adanya peran pembiasaan pelaksanaan ibadah shalat dzuhur para siswa dalam kehidupan sehari-hari. Peran dalam shalat dzuhur ini dilaksanakan bukan hanya guru PAI tetapi ketika seluruh guru terjadwal mengajar di

${ }^{25}$ Hasil Wawancara dengan Pak Bustomi

(Guru PAI Kelas X) pada Tanggal 24 Juli 2017 124

26 Oemar Malik,Proses Belajar Mengajar,...

27 Hasil Wawancara dengan Pak Bustomi

(Guru PAI Kelas X) pada Tanggal 24 Juli 2017 kelas seluruh guru itu aganr mendapingi ketika shalat dzuhur, tetapi kontrol itu ada pada guru PAI jadi guru PAI yang mengontrol seluruh kelas khususnya kelas $\mathrm{X}$ IPS1 karena guru PAI selalu senantiasa mengingatkan dan mengajarkan para siswanya untuk melaksanakan ibadah shalat para guru juga melaksanakan sholat dalam kehidupan sehari-hari baik lingkungan sekolah mauapun luar sekolah. ${ }^{27} \mathrm{~b}$. Mengingat para siswa untuk mengikuti sholat terutama shalat dzuhur disekolah. Para guru PAI tidak mengenal kata bosan, walau setiap harinya mengingat, mengajak dan mengontrol di setiap kelas, dengan guru berperan seperti ini maka akan timbul kesadaran diri sendiri pada siswa supaya kenapa? supaya kedepannya shalat dzuhur ini bukan hanya tertanam di sekolah saja. Jadi dia terbiasa ketika diluar sekolah atau sudah lulus. Jadi sudah terbiasa untuk melaksanakan shalat dzuhur khususnya shalat dzuhur ini sangat signifikan peningkatannya karena kenapa ?karena shalat dzuhur ini ontime khususnya guru PAI itu hadir di tengah-tengah ketika dalam melaksanakn shalat dzuhur ${ }^{28}$. Dengan caramengingatkan akan pentingnya shalat dzuhur setiap kali guru PAI mengajar dalam kelas dan mengkoodinir setiap kelas saat menjelang shalat dzuhur ${ }^{29}$.

28 Hasil Wawancara dengan Pak Bustomi (Guru PAI Kelas X) pada tanggal 24 Juli 2017

${ }^{29}$ Hasil Wawancara (Siswa Kelas X IPS1), Senin 24 Juli 2017 


\section{c. Guru Berperan Sebagai Pemimpin}

Guru harus mempunyai jiwa kepemimpinan yang baik seperti, merencanakan, melaksanakan, dan mengontrol. ${ }^{30}$ Semua akan menjadi contoh bagi siswa. Sementara data di lapangan menunjukan adanya peran guru PAI dalam meningkatkan kesadaran beribdah shalat dzuhur siswa yaitu dengan memberikan tauladan kepada siswanya dengan aktif juga mengikuti kegiatan sholat dzuhur baik di sekolah maupun di lingkungan masyarakat. Peran guru ketika sudah jam 11.45 mengarahkan siswa untuk langsung menuju ke musholah atau di dalam kelas khususnya kelas X IPS1. Karena IPS1 berada di lantai tiga jadi sedikit kesulitan, harus perlu ekstra dan kepemimpinan guruguru dalam membimbing, mengarahkan. Karena setiap waktu dzuhur guru-guru itu berada di kelas mereka yang mengajar pada waktu dzuhur, mereka yang akan menjadi imam atau menjadi pendamping dan pemimpin siswa ketika mereka shalat dzuhur. ${ }^{31}$

\section{d. Guru Berperan Sebagai Ilmuwan Guru sebagai orang yang} paling berpengetahuan, guru bukan saja berkewajiban menyampaikan pengetahuan yang di milikinya kepada siswa tetapi juga berkewajiban mengembangkan pengetahuan itu terus menerus memupuk pengetahuan yang telah di milikinya. ${ }^{32}$ Guru hendaknya

30 Oemar Malik, Proses Belajar Mengajar,...

31 Hasil Wawancara dengan Pak Bustomi

(Guru PAI Kelas X) pada tanggal 24 Juli 2017

32 Oemar Malik, Proses Belajar Mengajar,...

\begin{abstract}
senantiasa memperbaharui ilmu pengetahuannya. Upaya memperbaharui ilmu dan pengetahuan bisa ditempuh melalui membaca, menghadiri forum ilmiah, atau studi lanjut. Dengan ilmu pengetahuan yang memadai guru berkewajiban menyebarkan kepada siswa, Bahkan kalau perlu mengaplikasikan ilmu dan pengetahuan yang dimiliki dalam kehidupan masyarakat, guru disini sudah mengaplikasikan atau menyebarkan apa yang dimiliki guru pada pengetahuannya dan juga mengembangkan pengetahuan yang di miliki oleh siswa. ${ }^{33}$
\end{abstract}

\section{e. Guru Berperan Sebagai Penghubung \\ Guru sekolah memegang} peran sebagai penghubung di mana guru ber fungsi sebagai pelaksana, banyak cara yang di lakukan oleh guru untuk menghubungkan sekolah dengan masyarakat. ${ }^{34}$ Guru di SMA Muhamadiyah 1 Palembang berperan menjembatani antara generasi, budaya, dan lingkungan lama dengan yang baru.Dimana guru disini selalu mencontohkan perilaku-perilaku yang baik terhadap siswa maupun lingkungan sekitar dan lingkungan dimana pun. Guru menjadi jembatan penghubung dimana perilaku guru akan selalu di lihat seorang siswa dan harus sesuai dengan apa yang ada di lingkungan sekolah maupun dilingkungan masyarakat. ${ }^{35}$ Selain itu juga guru menjadi penghubung anatara kemajuan sekarang

33 Hasil Wawancara dengan Pak Bustomi (Guru PAI Kelas X) Tanggal 13 November 2017

34 Oemar Malik, Proses Belajar Mengajar,... 126

35 Hasil Wawancara dengan Pak Bustomi (Guru PAI Kelas X) Tanggal 13 November 2017 
mengantarkan suatu siswa dan masyarakat menujudari tidak tahu menjadi tahu. Dari tidak pandai menjadi pandai, dari tidak berdaya menjadi berdaya. ${ }^{36}$

\section{f. Guru Berperan Sebagai Pemba- haru}

Guru berperan sebagai pembaharu, oleh karena itu melalui kegiatan guru menyampaikan ilmu dan teknologi, contoh-contoh yang baik, dan lain-lain maka akan menanamkan jiwa pembaharu di kalangan siswa. ${ }^{37}$

Pembaharuan pendidikan bisa terjadi dimana-mana dalam semua aspek.Peran guru dalam pembaharuan pendidikan sangat strategis. Sebagai pelaksanaan pendidikan guru bisa melakukan pembaharuan dalam metode dan strategi pembelajaran, rencana pembelajaran dan aspek pendidikan lainnya karena guru di SMA Muhammadiyah 1 Palembang ini sebagai panutan atau contoh yang baik untuk para siswa dan siswi. ${ }^{38}$

\section{g. Guru Berperan Sebagai Pembangunan}

Guru merupakantoko guru pembangunan. Dalam banyak kasus kemajuan suatu negara sangat dipengaruhi kemajuan pendidikan. ${ }^{39}$ SMA Muhamadiyah 1 Palembang Salah satu faktor pendukung kemajuan pendidikan

\footnotetext{
36 Hasil Wawancara (Siswa Kelas X IPS1) pada hari Senin 13 November 2017

37 Oemar Malik, Proses Belajar Mengajar, (Jakarta: PT Bumi Aksara, 2001), 126

38 Hasil Wawancara dengan Ibu Siti (Guru PAI Kelas X) pada Tanggal 13 November 2017 39 Oemar Malik, Proses Belajar Mengajar,...

adalah peran guru yang kreatif dan cerdas akan memberikan pengaruh besar terhadap kemajuan pendidikan. Dengan kata lain kemajuan pendidikan identik dengan guru yang berkualitas. Sekolah yang memiliki guru-guru berkualitas akan lebih mudah melakukan pembangunan. Hal ini disebabkan guru dalam membekali peserta didik dengan berbagai ilmu pengetahuan dan ketrampilan lebih baik. $^{40}$ Selain itu guru juga ingin memajukan sekolah dengan tujuan, visi, dan misi yang tertera pada SMA Muhammadiyah 1 Palembang. ${ }^{41}$ \begin{tabular}{lll}
\multicolumn{1}{c}{ Bagi seorang guru agama, } \\
yang & terpenting
\end{tabular} kepribadiannya. Keperibadiannya itulah akan menentukan apakah ia akan menjadi pendidikatau pembina yang baikbagi anak didiknya, ataukah akan menjadi perusak atau penghancur bagi masa depan anak didik. Di sekolah figur guru merupakan peribadi kunci. Guru lah panutan utama pada anak didik, semua sikap dan perilakuakan dilihat, di dengar dan ditiru oleh anak didik, begitu juga tentang pelaksanaan ibadah sholat dzuhur. 42

Berdasakan hasil observasi, wawancara maka peran guru PAI dalam meningkatkan kesadaran beribadah shalat dzuhur kelas $\mathrm{X}$ IPS1 di SMA Muhammadiyah 1 Palembang sudah berperan. Sesuai dengan kedudukannya sebagai

40 Hasil Wawancara Dengan Pak Bustomi (Guru PAI Kelas X) pada Tanggal 13 November 2017

41 Hasil Wawancara (Siswa Kelas X IPS1), Senin 13 November 2017

42 Hasil Observasi pada Pembelajaran PAI pada hari Selasa 18 Juli 2017 
seorang peran pendidik haruslah orang yang baik, dan yang merasa menjadi pengajar, pembimbing,pemimpin, ilmuwan, penghubung, pembaharu, dan pembangunan, dan tanggung jawab untuk melatih para siswanya agar menjadi orang-orang muslim yang baik yang akan menjalani hidup mereka sesuai dengan etika yang di ajarkan islamdan juga ketika guru sedang mengajar di kelas, guru datang tepat waktu, berdo'a sebelum pelajaran dimulai, memberikan motivasi menyuruh siswa untuk membaca doa ibadah yang dipelajari, Terlihat dari para peran guru PAI di SMA Muhammadiyah 1 Palembang dengan senantiasan mengajak/menyeru para siswa untuk senantiasa melaksanakan shalat dzuhur. ${ }^{43}$

Dalam menjalankan peran sebagai guru PAI untuk dapat meningkatkan kesadaran beribadah shalat dzuhur berjamaah siswa tidak lepas dari yang namanya proses, untuk meningkatkan kesadaran beribadah pada siswa dengan menggunakan berbagai cara, yaitu: bimbingan atau penyuluhan, pemberian contoh yang teladan, dan memotivasi. Sesuai tujuan sekolah yakni dapat meningkatkan keimanan dan ketaqwaan kepada Allah SWT, maka setiap guru mampu mengamalkan setiap keyakinan dalam kehidupan seharihari dan dengan semangat menjalankan perannya di SMA Muhammadiyah 1 Palembang.

${ }^{43}$ Hasil Observasi pada Pembelajaran PAI pada hari Selasa 18 Juli 2017

44 Hasil Wawancara dengan Pak Bustomi (Guru PAI Kelas X) pada Tanggal 2 Oktober 2017
Langkah-langkah adanya peran guru PAI untuk dapat meningkatkan kesadaran beribadah shalat berjamaah siswa dengan cara: 1. Pembiasaan. Langkah pembiasaan ini dilakukan secara rutin setiap hari. adanya jadwal iman dan jadwal kelas yang melaksanakan shalat di mushalla pada setiap harinya, harapannya siswa dapat melaksanakan Shalat terkhusus terlaksana pada ketetapan waktu. 2. Memotivasi. Memberikan motivasi itu sangat dianjurkan, pemberian motivasi adalah salah satu cara yang efektif untuk menumbuhkan sifat kedisiplinan siswa terhadap apa yang mereka pelajari karena selain dapat menumbuhkan kesadaran ber-ibadah siswa, memotivasi juga dapat menjadikan siswa lebih tekun dalam ranah meningkatkan ibadah siswa, baik yang di rumah maupun disekolah. ${ }^{44}$ Oleh karena itu sebagai guru Pendidikan Agama Islam sangatlah penting perannya dalam mendidik siswa untuk menjadi yang lebih baik. 3. Contoh dan Tauladan . Guru SMA Muhammadiyah 1 Palembang selalu berusaha untuk memberikan contoh dan tauladan yang baik dan ikut serta melaksanakan secara berjamaah bersama murid. 45 4. Penyadaran. Penyadaran ini diberikan ketika berlangsungnya proses belajar mengajar, tepatnya pelajaran Fiqh. Dari hasil wawancara peneliti bahwa Memberikan materi karena materi yang di ajarkan khususnya kelas X ada materi masalah ibadah jadi siswa itu sebelumnya belajar

${ }^{45}$ Hasil Wawancara dengan Pak Bustomi (Guru PAI Kelas X) pada Tanggal 2 Oktober 2017 
materi inti setiap pagi mereka di ajarkan untuk bacaan ibadah bacaan shalatnya di kontrol dan harus hapal. Jadi, untuk ibadah siswa sendiri tidak terlalu repot karena mereka telah hapal semua dan telah tau gerak-gerakan menurut sunah yang di ajarkan pada Rasulullah SAW.46 5. Pengawasan. Pengawasan dilakukan oleh para guru dengan secara langsung bergerak menuju kelas yang menjadi tanggung jawabnya untuk menuju mushola sebagai tempat pelaksanaan beribadah shalat dzuhur berjamaah.

Shalat dzuhur ini dilaksanakan bukan hanya guru PAI tetapi seluruh guru ketika guru terjadwal di kelas seluruh guru itu akan mendampingi atau guru fisika yang mendampingi ketika sholat dzuhur. Tetapi kontrol itu ada pada guru PAI. Guru PAI yang mengontrol seluruh kelas khususnya kelas X IPS1 karena berada dilantai tiga jadi harus melihat langsung atau mengecek kepada seluruh kelas bagaimana siswa itu telah melaksanakan shalat apa belum sehingga ketika di kontrol akan timbul kesadaran diri sendiri pada siswa supaya kenapa? supaya kedepannya sholat dzuhur ini bukan hanya saja tertanam disekolah jadi dia terbiasa ketika dia dari sekolah atau lulus. Jadi, sudah terbiasa untuk melaksanakan sholat dzuhur khususnya shalat dzuhur ini sangat signifikan peningkatannya. ${ }^{47}$

Berdasarkan hasil observasi dan wawancara di atas maka adanya peran

46 Hasil Wawancara dengan Ibu Siti (Guru PAI Kelas X) pada Tanggal 2 Oktober 2017 guru PAI dapat meningkatkan kesadaran beribadah shalat dzuhur berjamaah siswa di SMA Muhammadiyah 1 Palembang. Sesuai dengan kedudukannya haruslah sesuai sebagai seorang peran pendidik yaitu : pembiasaan, memotivasi, contah dan tauladan, penyadaran, dan pengawas.

\section{KESIMPULAN}

Dari hasil pengkajian data dan analisis yang mendalam, penelitian ini menghasilkan kesimpulan sebagai berikut:

1. Kesadaran beribadah shalat dzuhur Siswa kelas X IPS 1 di SMA Muhammadiyah 1 Palembang terdapat berbagai tipe, yaitu: a. para siswa yang kesadarannya sangat bagus/baik; b. para siswa yang kesadarannya masuk dalam kategori cukup dengan indikator mereka shalat belum termotivasi dari dalam dirinya sendiri; c. para siswa yang kesadaran beribadahnya kurang dan masih perlu banyak di tingkatkan lagi, siswa tersebut melaksanakan ibadah shalat dikarenakan adanya paksaan dari guru yang mengontrol.

Faktor-Faktor kesadaran siswa dalam beribadah, yaitu: a. faktor intern atau faktor yang berasal dari dalam diri siswa yang mencakup biologis siswa; b. Faktor ektern seperti faktor keluarga, faktor sekolah hingga faktor masyarakat.

2. Peran Guru PAI dalam Meningkatkan Kesadaran Beribadah Shalat Dzuhur Siswa Kelas X IPS1 di SMA

\footnotetext{
${ }^{47}$ Hasil Wawancara dengan Pak Bustomi (Guru PAI Kelas X) pada Tanggal 2 Oktober 2017
} 
Muhammadiyah 1 Palembang adalah sebagai berikut: a. Guru berperan sebagai pengajar; b. Guru berperan sebagai pembimbing; c. Guru berperan sebagai pemimpin; d. Guru berperan sebagai ilmuwan. Guru hendaknya senantiasa memperbaharui ilmu pengetahuannya; e. Guru berperan sebagai penghubung; f. Guru berperan sebagai pembaharu. Peran-peran di atas dilaksanakan oleh guru PAI untuk dapat meningkatkan kesadaran beribadah shalat dzuhur berjamaah siswa dengan cara: a. pembiasaan; b. motivasi; c. contoh dan tauladan; d. penyadaran; dan e. pengawasan.

\section{DAFTAR PUSTAKA}

Al-Quran dan Terjemah. (2013). Bandung: Departemen Agama Republik Indonesia.

Hamalik, O. (2001). Proses Belajar Mengajar. Jakarta: PT Bumi Aksara.

Hasil Wawancara dengan Pak Bustomi (Guru PAI Kelas X) pada Tanggal 24 Juli 2017

Hasil Wawancara dengan Ibu Siti (Guru PAI Kelas X) Pada tanggal 24 Juli 2017

Hasil Observasi Siswa Kelas X IPS 1 pada hari Rabu Tanggal 19 Juli dan Selasa 8 Agustus 2017.
Hasil Wawancara (Siswa Kelas X IPS1) pada hari Senin 13 November 2017.

Hawi, A. (2013). Kompetensi Guru Pendidikan Agama Islam. Jakarta: PT Raja Grafindo Persada.

Kunandar. 2009. Guru Profesioal. Jakarta: Raja Wali Press.

Rusmaini. 2013. Ilmu Pendidikan, Depok: Pustaka Felicha. 